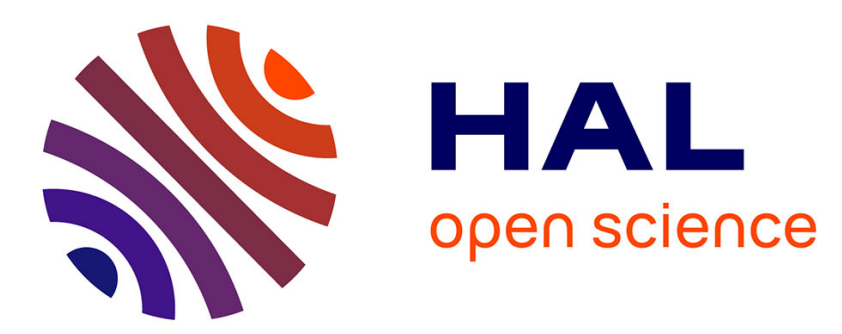

\title{
Inflammation Dysregulates Notch Signaling In Endothelial Cells: Implication Of Notch2 And Notch4 To Endothelial Dysfunction
}

Thibaut Quillard, Julie Devallière, Stéphanie Coupel, Béatrice Charreau

\section{- To cite this version:}

Thibaut Quillard, Julie Devallière, Stéphanie Coupel, Béatrice Charreau. Inflammation Dysregulates Notch Signaling In Endothelial Cells: Implication Of Notch2 And Notch4 To Endothelial Dysfunction. Biochemical Pharmacology, 2010, 80 (12), pp.2032. 10.1016/j.bcp.2010.07.010 . hal-00637150

\section{HAL Id: hal-00637150 \\ https://hal.science/hal-00637150}

Submitted on 31 Oct 2011

HAL is a multi-disciplinary open access archive for the deposit and dissemination of scientific research documents, whether they are published or not. The documents may come from teaching and research institutions in France or abroad, or from public or private research centers.
L'archive ouverte pluridisciplinaire HAL, est destinée au dépôt et à la diffusion de documents scientifiques de niveau recherche, publiés ou non, émanant des établissements d'enseignement et de recherche français ou étrangers, des laboratoires publics ou privés. 


\section{Accepted Manuscript}

Title: Inflammation Dysregulates Notch Signaling In Endothelial Cells: Implication Of Notch2 And Notch4 To

Endothelial Dysfunction

Authors: Thibaut Quillard, Julie Devallière, Stéphanie Coupel,

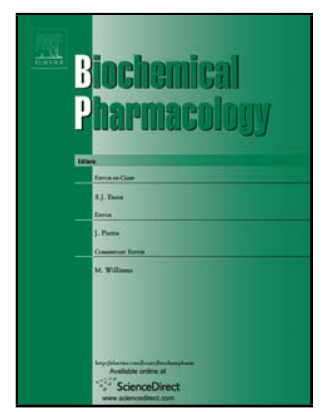

Béatrice Charreau

PII:

S0006-2952(10)00521-6

DOI:

doi:10.1016/j.bcp.2010.07.010

Reference:

BCP 10643

To appear in: $\quad B C P$

Received date: $\quad 27-4-2010$

Revised date: $\quad 2-7-2010$

Accepted date: $\quad 8-7-2010$

Please cite this article as: Quillard T, Devallière J, Coupel S, Charreau B, Inflammation Dysregulates Notch Signaling In Endothelial Cells: Implication Of Notch2 And Notch4 To Endothelial Dysfunction, Biochemical Pharmacology (2010), doi:10.1016/j.bcp.2010.07.010

This is a PDF file of an unedited manuscript that has been accepted for publication. As a service to our customers we are providing this early version of the manuscript. The manuscript will undergo copyediting, typesetting, and review of the resulting proof before it is published in its final form. Please note that during the production process errors may be discovered which could affect the content, and all legal disclaimers that apply to the journal pertain. 


\title{
BCP-D-10-00475R1
}

Biochemical Pharmacology/ Special Issue: Inflammation2010- Luxembourg

\section{INFLAMMATION DYSREGULATES NOTCH SIGNALING IN ENDOTHELIAL CELLS: IMPLICATION OF NOTCH2 AND NOTCH4 TO ENDOTHELIAL DYSFUNCTION}

\author{
Thibaut Quillard $^{1 \dagger}$, Julie Devallière $^{1}$, Stéphanie Coupel $^{1}$ and Béatrice Charreau ${ }^{{ }^{*}}$ \\ INSERM, U643, Nantes, F44000 France; CHU Nantes, Institut de Transplantation et de \\ Recherche en Transplantation, ITERT, Nantes, F44000 France; Université de Nantes, \\ Faculté de Médecine, Nantes, F44000 France.
}

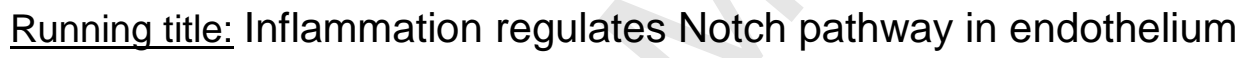

Key words: endothelium, inflammation, Notch, cell signalling, apoptosis, TNF

* corresponding author: Dr. Béatrice Charreau, PhD, INSERM U643, ITERT, CHU Hôtel-

Dieu, 30 Bd Jean Monnet, F-44093 Nantes, Tel. +33 240087 416; Fax. +33 240087 411;

email : Beatrice.Charreau@univ-nantes.fr

${ }^{\dagger}$ present address: Cardiovascular Medicine, Brigham and Women’s Hospital, Harvard Medical School, Boston, MA, USA 


\begin{abstract}
Although the involvement of the Notch pathway in several areas of vascular biology is now clearly established, its role in vascular inflammation at the endothelial level remains to be elucidated. In this study, we demonstrated that proinflammatory cytokines drive a specific regulation of the Notch pathway in vascular endothelial cells (ECs). In arterial ECs, TNF $\alpha$ strongly modulates the pattern of Notch expression by decreasing Notch4 expression while increasing Notch2 expression. Changes in Notch expression were associated with a reduction in hes1 and hey2 expression and in CBF1 reporter gene activity, suggesting that TNF $\alpha$ regulates both Notch expression and activity. Notch2 and Notch4 regulations occurred independently and were found to be mostly mediated by the NFאB signaling pathways and PI3-kinase signaling pathways, respectively. Functionally, TNF-mediated Notch regulation promotes caspase-dependent EC apoptosis. Finally, our findings confirmed that dysregulated Notch signaling also occurs upon inflammation in vivo and correlates with caspase activation and apoptosis. In conclusion, inflammatory cytokines elicit a switch in Notch expression characterized by Notch2 predominance over Notch4 leading to a reduced Notch activity and promoting apoptosis. Thus, here we provide evidence for a role of soluble mediators of inflammation (i.e. cytokines) in the regulation of Notch signaling and for the implication of a dysregulated Notch pathway to endothelial and vascular dysfunction.
\end{abstract}

(211 words) 


\section{Introduction}

Notch signaling is an evolutionarily conserved pathway that allows cell communication through molecular cell/cell interactions [1]. Notch encodes a single pass transmembrane protein with epidermal growth factor (EGF) repeats in the extracellular domain and ankyrin repeats in the intracellular domain that can binds to two different ligands, Delta and Serrate/Jagged. Vertebrates express multiple Notch receptors (Notch 1 to 4 ) and ligands including Delta-like (DII) 1, 3 and 4, and Jagged 1 and 2. The Notch receptors undergo three successive cleavages before allowing transcription of downstream targets. The first proteolytic event occurs in the trans-Golgi network by a furin-like convertase and leads to the cell surface presentation of a functional heterodimeric form of the receptors. The second cleavage, mediated by a disintegrin and metalloprotease (ADAM) family member, occurred after interaction with a ligand expressed on neighboring cells. Finally, the $\gamma$-secretase complex allows the cytoplasmic release of the intracellular domain of the receptor. This fragment is then translocated into the nucleus where it binds to the mammalian transcription factor CBF1/RBP-Jk docked in a transcriptional repressor complex. This interaction ultimately leads, through displacing the silencing complex and by the recruitment of coactivator factors, to the expression of primary target genes such as the hes and herp/hey genes [2]. Many studies have reported that the Notch pathway plays a fundamental role in drosophila and mammal development [1]. More recently, it was shown that Notch also plays major roles in the adult in several contexts involving cell plasticity, such as proliferation, oncogenesis [3], immune recognition [4], and angiogenesis [5].

Endothelial cells (ECs) control vascular tone, leukocyte adhesion, coagulation and thrombosis by a fine-tuned regulation of many cell surface and soluble molecules [6]. EC activation is considered to be an early event which subsequently leads to EC dysfunction and ultimately to vascular injury, key events associated with acute and chronic inflammation, including sepsis, atherosclerosis and acute vascular and chronic allograft rejection [7] [8]. EC changes involve membrane damage, increased permeability, swelling, apoptosis and 
necrosis. The EC loss of function could be as a result of changes in hemodynamic forces

(shear and/or hoop stress), direct drug-induced cytotoxicity, mechanical device implantinduced injury and/or immune-mediated mechanisms [9] [10]. Inflammatory signaling cascades alter EC integrity by enhancing expression of cellular adhesion molecules, activation of cytotoxic T cells and/or induction of antibodies directed against EC surface [7]. Local release of inflammatory cytokines, including TNF $\alpha$ and IL-1 1 , and chemokines activate ECs to upregulate soluble adhesion molecules, activate neutrophils and generate reactive oxygen species that amplify the initial inflammation leading to dysregulated apoptosis, secondary necrosis and overt vascular injury lesions. Considering the role of the endothelium in the initiation and propagation of vascular wall injury, there is a need for the discovery of molecular targets to serve as inhibitors of EC activation, dysfunction and vascular injury [6].

Both embryonic and adult ECs express Notch receptors and Notch ligands [2]. Notch signaling has been extensively implicated in endothelial cell-fate determination along vasculogenesis and angiogenesis [11]. Several studies examining the effects of activated Notch signaling on EC phenotype and function have identified potential mechanisms including endothelial-to-mesenchymal (EMT) transformation [12], EC proliferation [13] and control of apoptosis [14]. Recent findings further suggest a potential role for deregulated Notch signaling in tumor angiogenesis and metastasis [15]. It has also been reported that Notch may be necessary for the establishment and/or maintenance of quiescent EC phenotype [16]. However, implication of Notch signaling in activated EC phenotype and function upon inflammation has not been documented.

In previous studies, we investigated signaling pathways regulated by $\mathrm{TNF} \alpha$ in vascular ECs [17-20]. Of particular interest, we have shown that the desintegrin and metalloproteinase known as Kuzbanian or ADAM-10 is strongly upregulated at mRNA and protein level in ECs activated with TNF $\alpha$ [17]. ADAM-10 is involved in the processing of Notch receptors and ligands [21], suggesting a potential crosstalk between TNF signaling and Notch pathway that may contribute to changes in EC phenotype and functions. We also reported on the 
contribution of Notch signaling in transplant arteriosclerosis and endothelial injury [22, 23]. In this study, we investigated the regulation of Notch receptors and effector molecules in human vascular ECs upon stimulation with $\mathrm{TNF} \alpha$ and other pro-inflammatory mediators in vitro and in vivo. Moreover, the overall Notch activity and the respective involvement of TNF $\alpha$ mediated signaling pathways, including NFKB, PI-3 kinase and JNK MAPK, in Notch regulation was also examined. 


\section{Material and Methods}

\subsection{Cell culture and reagents}

Primary cultures of human ECs issued from segments of renal artery (HAEC) or from human umbilical veins (HUVEC) were isolated and cultured as we previously reported [19]. ECs were grown in endothelial basal growth medium (ECBM, Promocell, Heidelberg, Germany) supplemented with $10 \%$ fetal calf serum (FCS), $0.4 \%$ EC growth supplement/heparin, $0.1 \mathrm{ng} / \mathrm{mL}$ human epidermal growth factor, $1 \mathrm{ng} / \mathrm{mL}$ human basic fibroblast growth factor, $1 \mu \mathrm{g} / \mathrm{mL}$ hydrocortisone, $50 \mu \mathrm{g} / \mathrm{mL}$ gentamicin, and $50 \mathrm{ng} / \mathrm{mL}$ amphotericin B (Promocell). Before activation, confluent EC monolayers were growth factor and serum depleted by culture for $24 \mathrm{~h}$ in basal ECBM supplemented with only $2 \%$ FCS. For activation, confluent EC monolayers were cultured with $100 \mathrm{U} / \mathrm{mL}$ recombinant human gamma interferon (IFN $\gamma$ ) (Imukin, Boehringer Ingelheim, Germany) or human tumor necrosis factor-alpha (TNF $\alpha$ ) (provided by Professor P. Neuman, BASF, Ludwigshafen, Germany). Human Recombinant IL1 $\beta$ (R\&D Systems, Abingdon, UK) was used at $5 \mathrm{ng} / \mathrm{mL}$. For inhibition experiments, SP600125 (10 $\mu \mathrm{M}), \mathrm{N}$-acetyl-cysteine (NAC, $10 \mathrm{mM}$ ), pyrrolidine dithiocarbamate (PDTC; $100 \mu \mathrm{M}$ ) and wortmannin (100 nM) (all purchased from SigmaAldrich, Saint Quentin Fallavier, France) were added to cells $1 \mathrm{~h}$ before TNF $\alpha$ treatment.

\subsection{Recombinant adenovirus, SiRNAs, plasmids and transfection}

The recombinant adenovirus for Notch2NICD and GFP (AdN2ICD) was generated as we previously described [23] and produced in the 293 cells by the vector core laboratory of the University Hospital of Nantes (INSERM UMR649 Gene Therapy Laboratory, Nantes, France). The recombinant adenovirus AdTrack-GFP was used as control (AdGFP). Adenoviral infection was carried out in ECGM supplemented with $1 \%$ FCS for 3 h at $37^{\circ} \mathrm{C}, 5 \%$ $\mathrm{CO}_{2}$ under agitation. Transduction efficiency was analyzed 24h after infection through GFP 
detection by direct microscopy imaging and Flow Cytometry using a FACScalibur ${ }^{\circledR}$ (BD Biosciences, Franklin Lakes, NJ, USA).

For gene silencing, cells were transfected according to manufacturer's recommendations with RNAiMax lipofectamine ${ }^{\circledR}$ (Invitrogen, Cergy Pontoise, France) and siRNA targeting Notch4 (\#107458, 95\% knockdown, \#107459, 74\% knockdown), or a scrambled negative control (\#AM4611) (Ambion, Austin, TX, USA) at a final concentration of 10nM. Specific expression knockdown by siRNA was attested by qRT-PCR and functional assays were assessed $48 \mathrm{~h}$ post-transfection.

\subsection{Semi-quantitative RT-PCR, quantitative real-time PCR and Southern blotting}

RNA was isolated using Trizol reagent (Invitrogen, Carlsbad, CA, USA) and treated with DNase (Ambion) before reverse transcription (RT). Subsequent to RT, cDNA were amplified by PCR and analyzed in agarose gels stained with ethidium bromide. For semiquantitative RT-PCR, PCR conditions were optimized for each primer set and performed for 18 to 35 cycles of amplification to allow semiquantitative analysis (Table 1). For Southern blotting, PCR products were purified according to the nucleospin extract II protocol (Macherey-Nagel, Hoerdt, France). Purified amplicons were then cloned into the TOPO TA cloning ${ }^{\circledR}$ vector (Invitrogen) and sequenced before their use as CDNA probes. Southern blotting and hybridizations were performed as we previously described [17]. Quantitative PCRs were performed using the ABI PRISM 7700 sequence detection application program (PE Applied Biosystems, Foster City, CA, USA). For quantification, duplicates were normalized by the concomitant quantification of hypoxanthine-guanine phosphoribosyl transferase (HPRT). Normalization was made with the control samples in the human cells and with an additional reference sample for the rat study. Relative expression was calculated according to the $2^{-\Delta \Lambda C t}$ method, as previously described [24]. Custom primers were obtained from MWG (High Point, NC, USA) and used for semiquantitative PCR and QPCR (Table 1). Transcript levels were quantified by GRT-PCR with the following primers and probe from Applied Biosytems (Foster City, CA, USA): Notch1 (Hs00413187_m1), Notch2 
(Hs00225747_m1; Rn00577522_m1), Notch4 (Hs00270200_m1; Rn01525737_g1), hey1 (Hs00232618_m1), VCAM-1(Hs00365486_m1; Rn00563627_m1) and HPRT (Rn01527838_g1).

\subsection{Immunoblotting}

Cells were lysed on ice in $20 \mathrm{mmol} / \mathrm{L}$ Tris- $\mathrm{HCl}(\mathrm{pH} 7.4), 137 \mathrm{mmol} / \mathrm{L} \mathrm{NaCl}, 0.05 \%$ Triton X-100, $1 \mathrm{mmol} / \mathrm{L}$ phenylmethylsulfonyl fluoride supplemented with protease inhibitors (PIC, Sigma-Aldrich). Lysates were resolved by sodium dodecyl sulfate-polyacrylamide gel electrophoresis $(6 \%-10 \%)$ and subjected to Western immunoblot analysis using specific antibodies against Notch2 (C651.6DbHN, Developmental Studies Hybridoma Bank, IA, USA), Notch4 (Santa Cruz Biotechnology, Santa Cruz, CA, USA), total and cleaved caspase 3 and 7 (Cell Signaling Technology, St Quentin-en-Yveline, France) and tubulin (Oncogene, MERCK EuroLab, Val de Fontenay, France), and secondary horseradish peroxidase-labeled anti-rabbit, anti-mouse, or anti-goat antibodies (Cell Signaling Technology). Antibody-bound proteins were detected using an enhanced chemiluminescence kit (ECL kit, Amersham, Les Ulis, France).

\subsection{Apoptosis Assays}

Measurement of caspase activity - Caspase activity was analyzed by western blot using antibodies against cleaved Caspase-3 (Asp175), cleaved Caspase-7 (Asp198), and antibodies against total caspase- 3 and -7 (all from CST).

The cell-permeable fluorogenic substrate PhiPhiLux-G2D2 (Oncolmmunin, Gaithersburg, MD) containing the cleavage site DEVD was used to monitor caspase-3-like activity in intact cells. ECs were incubated with the substrate solution for $1 \mathrm{~h}$ at $37^{\circ} \mathrm{C}$ in the dark, according to the manufacturer's instructions. Caspase 3 activation/apoptosis was examined during $18 \mathrm{~h}$ by time lapse imaging using a microscope DMI6000B (Leica Microsystems SAS. Rueil Malmaison) equipped with an objective lens X40 (HCX FL Plan), and a CCD camera (Coolsnap HQ2, Photometrics Roper Scientifics SAS Evry). Caspase 3 positive cells/field 
were counted every $2 \mathrm{~h}$ between $48 \mathrm{~h}$ and $66 \mathrm{~h}$ post-infection with AdN2ICD and controls adenovirus. Results were expressed as the percentage of caspase-postive ECs.

\subsection{Animal model of vascular inflammation}

The care and use of animals in this study complied with institutional guidelines. Male Sprague Dawley rats (300 to $400 \mathrm{~g}$ body weight) purchased from Charles River (Saint-Aubin, les Elbeuf, France) were injected intravenously, under anesthesia, with $10 \mu \mathrm{g} / \mathrm{kg}$ of recombinant rat TNF $\alpha$ (PreproTech, Neuilly-Sur-Seine, France) or PBS as vehicle. Animals were euthanized for organ collection 1, 4 or $6 \mathrm{~h}$ after treatment. Rat RNA and proteins were isolated using TriZol@ (Invitrogen) and RIPA (0.5\% sodium deoxycholic acid, $0.1 \%$ SDS, $1 \%$ NP40, PBS, protease inhibitors) buffers, respectively, and were then treated as reported above.

\subsection{Statistics}

Data are represented as means \pm SE for replicates experiments $(n=3$ independent experiments). Statistical analysis was performed on Graphpad Prism ${ }^{\circledR}$ Software (Graphpad Software, San Diego, CA) with the parametric or Kruskal Wallis non parametric analysis of variance test as appropriate. $p<0.05$ was considered statistically significant. 


\section{Results}

\subsection{Constitutive and cytokine-regulated expression of the Notch2 and Notch4 receptors in vascular cells}

To further characterize the vascular changes in expression and activity of the Notch pathway molecules upon inflammatory processes, we sought to analysis the pattern of mRNA levels for Notch receptors in resting and cytokine-activated vascular cells. To this aim, primary cultures of ECs from two different vascular beds (HAEC from arteries and HUVEC from veins) were treated for 0 to $24 \mathrm{~h}$ with recombinant tumor necrosis factor-alpha (TNF $\alpha$ ) and transcript levels were analyzed by semi-quantitative RT-PCR. As shown in Figures 1A and 1B, transcripts for the receptor Notch4 were detected in untreated vascular ECs whereas only minimal levels of Notch2 mRNA were found, indicating that quiescent ECs differentially express Notch receptors. TNF elicits an upregulation of Notch2 and a downregulation of Notch4 in both HAEC and HUVEC.

Quantitative PCRs confirmed that, in ECs, TNF $\alpha$ selectively modulates the mRNA steadystate levels for the Notch receptors. TNF $\alpha$ decreased transcript levels for Notch4 with a significant effect starting $2 \mathrm{~h}$ after treatment and maximal inhibition of $78 \pm 2 \%$ as compared with basal levels $\left({ }^{*} p<0.05\right)$ (Figure 1C). In contrast, an enhanced mRNA level for Notch2 was found in response to TNF $\alpha$, corresponding to a maximal $3.3 \pm 0.3$-fold increase at $24 \mathrm{~h}$ $\left({ }^{*} \mathrm{p}<0.05\right)$ as compared to the basal mRNA level. Western blotting analysis (Figure 1D) indicates that regulation in of Notch2, and 4 protein level paralleled changes in steady state mRNA levels for these molecules (up to $2.69 \pm 1.26$ and $0.28 \pm 0.02$-fold the baseline for Notch 2 and Notch 4, respectively; ${ }^{*} p<0.05$ ), suggesting that TNF $\alpha$ triggers an effective and selective Notch regulation at both mRNA and protein levels in ECs.

Next, we tested whether Notch expression could be regulated by cytokines other than TNF $\alpha$. To address this question, qRT-PCR was used to compare mRNA levels for Notch2 and Notch4 in ECs treated with the cytokines TNF $\alpha$, interleukin-1 $\beta$ (IL1 $\beta)$ and interferon $\gamma$ 
(IFN $\gamma)$ (Figure 2). A comparable regulation in both time course and magnitude was observed for Notch2 in ECs activated with TNF $\alpha$, IL1 $\beta$ or IFN $\gamma$ (up to a $2.3 \pm 0.3$-fold increase for Notch2 as compared with untreated cells). Notch4 exhibited the same pattern of regulation upon TNF $\alpha$ and IL1 $\beta$ stimulation, with a maximal decrease in mRNA of $65 \pm 5 \%$ and $69 \pm 1 \%$ for $\mathrm{TNF} \alpha$ and IL1 $\beta$, respectively. Regulation of vascular cellular adhesion molecule-1 (VCAM-1) is shown as a control of EC activation. Similarly to VCAM-1, IFN $\gamma$ had no significant effect on the reduction of Notch4 transcripts.

\subsection{TNFa-mediated regulation of Notch effectors and impact on basal Notch activity in cultured ECs.}

Expression of Hairy/Enhancer of split (hes) and Hairy-related (hey/hrt/herp) transcription factors has been shown to be regulated by activation of Notch receptors [25]. Consequently, activity of the Notch pathway should be reflected by the expression of the hes and hey transcripts. Cells were incubated with recombinant TNF $\alpha$ for 0 to $24 \mathrm{~h}$ and mRNA levels for hes-1, 2, 3, 4, 5, 6, and 7 and hey 1, 2 and 3 were analyzed by RT-PCR. As shown in Figures 3A, ECs basally express significant levels of hey1, hey 1 and hes 1 mRNAs. We found that transcript levels of hes2, 4 and 6 were lower than hes 1/hey1-2 (detection achieved at $>30$ cycles of PCR amplification, see also Table 1). In addition, no mRNA for hes3, 5 or 7 or hey3 was detected by RT-PCR (at 35 PCR cycles), suggesting that these effectors molecules are weakly expressed in ECs and play minor roles in Notch signal in ECs (data not shown) as compared to hes $1 /$ hey1-2. Among these molecular targets of Notch activity, only hey1 was found upregulated in TNF $\alpha$-activated ECs. In contrast, after TNF $\alpha$ treatment, hey2 and hes1 showed a significant decrease in their expression.

In parallel, the expression of effector molecules in response to TNF $\alpha$, IL1 $\beta$ and IFN $\gamma$ was investigated. As shown in Figure 3, a drastic down-regulation of both hes-1 and hey-2 was found in response to $\operatorname{TNF} \alpha(79 \pm 1 \%$ and $78 \pm 1 \%$ inhibition at $24 \mathrm{~h}$, respectively). 
Similarly, IL $1 \beta$ induced a comparable regulation pattern with a maximal inhibition achieved at $6 \mathrm{~h}$ for hes1 and at $12 \mathrm{~h}$ for hey2 $(52 \pm 3 \%$ and $71 \pm 4 \%$ of decrease, respectively, as compared to untreated cells). In addition, the enhancement of hey1 ( $2.2 \pm 0.3$-fold increase versus control) by TNF $\alpha$ was further observed with IL1 $\beta$ (6.5 \pm 1.6 -fold increase as compared to basal expression level). However, no significant regulation of these effector genes was obtained after IFN $\gamma$ treatment, suggesting selective Notch receptors/effectors regulations and therefore functions in response to inflammatory stimuli.

\subsection{TNF-mediated regulation of Notch2 and Notch4: involvement of NFKB, Pl-3 kinase and MAP kinase signaling pathways.}

The selective effects of inflammatory cytokines by TNFa, IL1 $\beta$ and IFNy on Notch molecules also suggest that specific signaling pathways are implicated in this process. In ECs, TNF $\alpha$ activates several signaling pathways including the phosphatidylinositol 3-kinase (PI3-K), nuclear factor- $\mathrm{K}(\mathrm{NF} \mathrm{KB})$ and mitogen-activated protein kinase (MAPK) pathways [26]. The respective involvement of these pathways in Notch regulation mediated by TNF $\alpha$ in ECs was examined. For this purpose, HAECs were pretreated with or without signaling pathway inhibitors (N-acetyl cysteine (NAC), PDTC, wortmannin and SP600125) for $1 \mathrm{~h}$ and then activated with $\mathrm{TNF} \alpha$ for $24 \mathrm{~h}$, a time point leading to maximal regulation as shown above. Transcript levels for Notch2 and 4 were determined by qRT-PCR.

We found that blocking PI3-K using wortmannin does not affect Notch4 downregulation triggered by $\mathrm{TNF} \alpha$ (Figure 4). In contrast, Notch2 transcriptional upregulation was totally inhibited. Inhibition of the PI3K as well as inhibition of JNK also significantly prevents transcriptional regulation of hey1. An efficient prevention of TNF $\alpha$ dependent Notch4 and hes1 downregulation was obtained after NFKB inhibition using PDTC or NAC. The blockade of C-Jun N-terminal kinase (JNK) MAPK with SP600125 has no effect on Notch 2, Notch4 and hes1 suggesting that this pathway is not involved. Overall, our data demonstrated for the first time that opposite regulations of Notch2 and Notch4 in activated 
EC require selective signaling pathways suggesting that Notch receptors exert non redundant, complementary, functions upon inflammation. Moreover, our data showing that hes/hey effector molecules are also selectively regulated by the NFKB and PI3Kinase pathways substantiated the hypothesis that Notch receptors control specific functions through the regulation of selected effectors (i.e. Notch2/hey1, Notch4/hes1).

Next, we used silencing experiments to mimic the changes in Notch4 expression mediated by TNFa in vascular ECs. To this aim, silencing of Notch4 was achieved using two different siRNAs targeting Notch4(SiN4\#1 and SiN4\#2) or a scramble non targeting SiRNA (scramble) as we previously described [22]. Cells were then analyzed by qPCR for Notch2 and Notch4 transcript levels. Notch1 mRNA was used as a control for potential off-target effects. We found that silencing Notch4 has no significant effect on Notch1 and Notch2 expression indicating that downregulation of Notch4 doesn't trigger the regulation of Notch2. Conversely, we also observed that silencing or overexpressing Notch2 has no regulatory effect of Notch4 expression in ECs (data not shown).

Overall, our findings suggest that TNF $\alpha$-mediated changes of Notch2 and 4 transcription may occur independently and are dependent, at least partially, on the PI3K and NFKB pathways and support a major role for NFkB in the control of Notch4 and hes1 [27].

\subsection{Endothelial changes in Notch2 and Notch4 expression promote EC apoptosis.}

Next, to functionally assess the impact of Notch regulation, apoptosis assays were performed after modulation of Notch2 and/or Notch4 in cultured ECs. We used gene transfer to mimic the changes in both Notch2 and Notch4 mediated by TNFa in vascular ECs. To this aim, silencing of Notch4 was achieved as above using siRNAs while Notch2 was modulated and activated using an adenoviral vector encoding Notch2-ICD and GFP (AdN2ICD) as we previously described [23]. Controls include a non targeting siRNA (scramble) and a recombinant adenovirus for the reporter gene GFP (AdGFP). Transduced and knock-down cells were then analyzed by Western blots for caspase activation. We found that silencing Notch4 and overexpression of Notch2 (NICD) similarly induce the cleavage of caspase-3 
(Asp175) and caspase-7 (Asp198) indicating that both events are pro-apoptotic in vascular ECs (Figure 5A). To confirm these results, caspase-3 activity was monitored in live ECs by videomicroscopy using a cell permeable substrate (PhiPhiLux ${ }^{\circledR}$ ) to detect real-time activation of caspase (Figures 5B, 5C, 5D, 5E). The PhiPhiLux probe becomes fluorescent (red) when cleaved by active caspase-3. For these experiments, ECs were silenced for Notch4, transduced using AdN2ICD or both. Higher basal caspase-3 activity in treated cells compared to control reflects the pro-apoptotic effect of Notch modulation (Figures 5B\&5C). Consistent with immunoblotting, we show a time-dependent increase in caspase-3 activity in ECs with a sustained Notch2 NICD expression or with a knocked-down for Notch4. Moreover, we found that combination of both further elicits caspase-3 activity suggesting that despite partly independent regulation of Notch2 and 4, apoptosis is a common effector mechanism. These data were further confirmed by annexin $\mathrm{V}$ labeling and facs analysis (data not shown).

\subsection{Modulation of Notch2 and Notch4 in vascular inflammation in vivo.}

In order to establish a preliminary evidence in vivo for the biological relevance of our in vitro findings related to Notch regulation in activated ECs, we investigated Notch expression in rats treated with recombinant TNFa. EC activation was assessed by measuring VCAM-1 expression, a representative marker of EC activation in vitro and in vivo [7]. To induce vascular inflammation and EC activation, rats were treated intravenously with recombinant TNF $\alpha$ or vehicle as control. At 0 to $6 \mathrm{~h}$ postinjection, kidney, heart and lung were collected for analysis. First, basal expression of Notch2 and 4 transcripts in the different tissues from untreated rats was compared by qRT-PCR. As shown in Figure 6A, the transcript level of Notch2 and 4 molecules varied greatly according to tissues, with the highest expression levels consistently observed in the lung. The lower levels of Notch2 and 4 transcripts were found in the heart. Ratios of expression levels in the lung compared with the heart were 16.2 \pm 3.0 -fold $\left({ }^{*} \mathrm{p}<0.05\right)$ for Notch2, and, $6.4 \pm 1.1$-fold $\left({ }^{*} \mathrm{p}<0.05\right)$ for Notch4. 
Expression of Notch receptors was further examined in lung from rats treated with TNF $\alpha$ for 1, 4 and $6 \mathrm{~h}$ (Figure 6B). Notch2 mRNAs were significantly and transiently increased (1.8 \pm 0.1 -fold increase as compared to untreated rats; $p<0.05$ at $1 \mathrm{~h}$ ). In contrast, Notch4 was downregulated upon TNF $\alpha$ treatment, with a maximal $2.2 \pm 0.1$-fold decrease in mRNA level, $(p<0.05$ versus control). Western blotting for Notch2 and Notch4 further confirmed the respective up- and down-regulation at the protein level in tissues (Figure 6C). We also performed immunochemistry analysis on lung sections and we confirmed the decrease at endothelial level of Notch4 in TNF-treated animals (data not shown). Unlike Notch4, Notch2 is ubiquitously expressed in cells and tissues and we were not able to appreciate a clear quantitative increase in Notch2 expression in the endothelium (data not shown). Immunoblotting experiments also associated Notch regulation with pro-apoptotic events reflected by the activation of caspase-3 and caspase-7. The 19-kDa form of cleaved caspase-3 (Asp175) and the 20-kDa form of cleaved caspase-7 5(Asp198) were detected in lung from TNF-treated but not in controls (Figure 6D).

\section{Discussion}

Although the impact of the Notch pathway in several areas of vascular biology is now clearly established, its role in vascular inflammation at the endothelial level remains to be elucidated. A large number of studies demonstrated, mostly through modulation of Notch pathway activity, that Notch is involved in EC differentiation, apoptosis and proliferation [12] [16] [28]. In addition, recent studies also investigated the effect of various effectors, such as soluble mediators of cell growth (VEGF or FGF-2) [28] [29], differentiation (TGF $\beta$ ) [30] or activation (LPS) [31] on the Notch pathway in various cell types. In the present study, we asked whether inflammatory mediators could also modulate the Notch signaling and the pattern of Notch molecules expressed in vascular endothelial cells. To this aim, the effect of cytokines on Notch receptors expression and on Notch activity in human ECs was examined.

Here, we demonstrated that TNF $\alpha$, the prototype of pro-inflammatory cytokines, drives a specific regulation of the Notch pathway in vascular ECs. In arterial ECs, TNF $\alpha$ strongly 
modulates the pattern of Notch molecules expression by decreasing Notch4 expression while increasing Notch2 expression. Changes in Notch levels were further observed at the protein level, and were associated with a reduction in hes-1 and hey-2 expression and CBF1 reporter gene activity as previously reported [23], suggesting that inflammation regulates both Notch expression and activity. Interestingly, regulation of Notch4 expression seems to be cytokine-specific since no regulatory effect was found in response to IFNy, similar to VCAM-1 that is not affected by IFNy. This TNF $\alpha$-driven transcriptional regulation was found to be mostly mediated by the NFKB and the PI3-kinase signaling pathways. In vivo analysis confirmed that in the lung, TNF $\alpha$ regulates Notch2 and Notch4 at both transcriptional and protein levels.

Four distinct Notch receptors, Notch1, 2, 3, and 4, and five different Notch ligands, Jagged1 and 2, and Delta-1, 3, and 4, have been identified and characterized in mammals. ECs express endothelium-specific Notch members, including Notch4 and DII-4. However, whether normal, quiescent, human ECs express basal levels of other Notch receptors and ligands is not clearly established. Here we show that Notch2 is also expressed in cultured ECs and is upregulated in response to TNF $\alpha$. However, the concomitant downregulation of Notch4 expression and Notch activity may suggest that Notch4 is the major Notch receptor in arterial ECs or that Notch2 partly exerts its functions by a non-canonical mechanism.

In contrast to ECs and consistent with previous data [32], we also found that vascular SMCs express Notch2 and Notch3 but not Notch4 at mRNA level. Consistent with our results on ECs, vSMCs responded to TNF $\alpha$ with a significant upregulation of Notch2 (about a 4.2fold increase as compared to untreated cells) and a strong downregulation of Notch3 expression (data not shown).

Associated with the constitutive expression of Notch receptors, we found a basal expression of a selective pattern of effector molecules of the Hairy/Enhancer of split (Hes) 
and Hairy-related transcription factors (Hey, also known as Hrt, Hesr, Hey, CHF, grl, and Herp) family. Previous studies showed basal transcript levels for hes1, hey1 (herp2, hrt1, hesr1) and hey2 (herp1, hrt2, hesr2) in ECs [25, 33]. Consistent with these results, we reported significant expression of hes-1 and 2 and hey- 1 and 2 associated with a basal CBF1/luciferase activity (data not shown), confirming that endogenous Notch activity occurs in quiescent ECs and is probably implicated in the maintenance of endothelium quiescence [34]. A microarray comparison of large series of human EC lines confirmed arterial-specific expression for hey2 [35]. Further, those authors showed that ectopic expression of hey2 in HUVECs specifically induces expression of a series of genes that are characteristic of arterial endothelia, implicating hey2 as a key regulator of the arterial phenotype. Consistent with our results, Espinosa et al. provided evidence that TNF $\alpha$ triggers an important decrease in the level of hes1 mRNA, while a lower effect was found on hey1 [36]. Our findings further indicate that, consistent with an overall decreased expression for the major effector molecules hes 1 and hey1, TNF $\alpha$ reduces basal CBF1 reporter activity in activated ECs. Considering that $\mathrm{CBF} 1$ activity reflects canonical Notch pathway activity, we may extrapolate that TNF $\alpha$ decreases Notch activity in ECs.

The functional consequences of Notch modulation mediated by TNF $\alpha$ in the endothelium appear to promote EC apoptosis. Notch4 has been implicated in the control of proliferation, apoptosis and migration of SMCs and ECs $[14,16,37]$. Notch2 has mostly been involved in monocyte and T lymphocyte maturation and differentiation [38-40]. Its role in EC biology is still unclear. We recently demonstrated that Notch2 signaling sensitizes EC to apoptosis [23]. TNF elicits a broad array of cellular effects via two receptors TNFR1 and TNFR2. TNFR1 mediates inflammation and cell death while TNFR2 serves to enhance TNFR1-induced apoptosis or to promote cell activation, migration, growth or proliferation in a cell-specific manner [41]. Here, our results suggest that concomitant changes in Notch2 and Notch4 expression elicited by TNFa may have an additive pro-apoptotic effect that triggers endothelial injury and vascular damage. 
To conclude, inflammatory cytokines trigger a selective expression pattern of Notch receptors in the endothelium associated with a reduced canonical Notch activity. Consistent with previous models where growth factors modulate the expression of Notch receptors and ligands at both qualitative and quantitative levels, our findings suggest that inflammation may provide additional control of Notch signaling.

\section{Contributors}

T.Q. contribute most of the experimental work and participated in the design or the study, data analysis and drafting the manuscript. J.D. contributed significantly to the in vitro experiments and apoptosis assays. S.C. performed initial in vivo experiments and analysis. B.C. performed conception and design of the study, contributed substantially to interpretation of the data and drafting of the manuscript. All authors read and approved the final manuscript.

\section{Acknowledgements}

The authors thank Flora Coulon and Nathalie Gérard for excellent technical assistance and Philippe Hulin and the "confocal microscopy and cellular imaging platform" of IFR26 for time lapse study. This work was supported by "Xenome", a European Commission-funded Integrated Project, Life Sciences, Genomics and Biotechnology for Health LSHB-CT-2006-037377, and by grants from La Société Francophone de Transplantation, La Société de Néphrologie and La Fondation Centaure and La Fondation Progreffe. T.Q. was supported by a grant from la Fondation pour la Recherche Médicale.

\section{Abbreviations}


ECs: endothelial cells; HAECs: human arterial ECs; HUVECs: human umbilical vein

ECs; ICD: intracellular domain; SMCs: smooth muscle cells.

\section{Figure Legends}

Figure 1.

Expression of Notch receptors in resting and TNF $\alpha$-activated endothelial cells.

Confluent cells monolayers were incubated with $100 \mathrm{U} / \mathrm{mL}$ TNF $\alpha$ for the indicated periods.

Cells were lysed in parallel experiments to allow RNA and protein analysis. Semiquantitative RT-PCR analysis of mRNA levels for Notch2 and 4 in vascular cells: HAEC (A), HUVEC (B). PCR products were separated on $1.2 \%$ agarose gels, blotted onto nylon membranes and hybridized with specific radiolabeled PCR probes. $\beta$-Actin mRNAs were amplified as normalization controls. Representative autoradiographs of three independent experiments are shown. (C) Real-time quantitative PCR for Notch2 Notch4, VCAM-1 in HAECs. Results shown are the mean \pm SEM from three independent experiments performed in duplicates and are expressed as relative expression, calculated according to the $2^{-\Delta \Lambda \mathrm{Ct}}$ method $\left({ }^{*} \mathrm{p}<\right.$ 0.05 versus control). (D) A representative analysis of Notch protein expression in HAEC by Western blotting. Blots were reprobed with an anti-tubulin antibody to ensure equal loading. (E) Quantification of western blot analysis for Notch2 and Notch4 from at least 4 independent experiments.

Figure 2. 
Comparative effects of various cytokines on Notch signaling. HAECs were treated for 0 ,

6, 12 and $24 \mathrm{~h}$ with TNF $\alpha(100 \mathrm{U} / \mathrm{mL}), \mathrm{IL} 1 \beta(5 \mathrm{ng} / \mathrm{mL})$ or IFN $(100 \mathrm{U} / \mathrm{mL})$. Transcriptional regulation was analyzed by Real-time quantitative RT-PCR for Notch2, Notch4 and VCAM-1. Results shown are the mean \pm SEM from three independent experiments performed in duplicates and are expressed as relative expression, calculated according to the $2^{-\Delta \Delta C t}$ method, after normalization to HPRT levels ( ${ }^{*} p<0.05$ versus control).

Figure 3.

Regulatory effects of TNF on Notch effectors and Notch activity. HAECs were treated for $0,2,6,12$ and $24 \mathrm{~h}$ with $\mathrm{TNF} \alpha(100 \mathrm{U} / \mathrm{mL}), \mathrm{IL} 1 \beta(5 \mathrm{ng} / \mathrm{mL})$ or IFN $\gamma(100 \mathrm{U} / \mathrm{mL})$. (A) Expression pattern of Notch effectors hes and hey was determined by semiquantitative RTPCR. PCR products were separated on $1.2 \%$ agarose gels and stained with ethidium bromide. $\beta$-actin mRNA was amplified as a control. Results are representative of three experiment performed. Transcriptional regulation was analyzed by real-time quantitative PCR for hes1 (B), hey1 (C) and hey2 (D). Results shown are the mean \pm SEM from three independent experiments performed in duplicates and are expressed as relative expression, calculated according to the $2^{-\Delta \Delta C t}$ method, after normalization to HPRT levels $\left({ }^{*} p<0.05\right.$ versus control).

Figure 4.

Signaling pathways involved in TNF $\alpha$-dependent Notch regulation. HAECs were preincubated with PDTC $(100 \mu \mathrm{M})$, SP600125 $(10 \mu \mathrm{M})$ or wortmannin $(100 \mathrm{nM})$ for $1 \mathrm{~h}$ before $24 \mathrm{~h}$ treatment with $\mathrm{TNF} \alpha(100 \mathrm{U} / \mathrm{mL})$. Cells were lysed to allow RNA analysis by quantitative RT-PCR for Notch2 (A), hey1 (B), Notch4 (C) and hes1 (D). Results shown are the mean \pm SEM from three independent experiments and are expressed as relative expression, calculated according to the $2^{-\Delta \Lambda C t}$ method, after normalization to $\beta$-actin levels. ${ }^{*} p<0.05$ versus TNF $\alpha$-untreated cells (ctrl) and between non pre-treated and pre-treated TNF $\alpha$-activated cells with inhibitors. (E) ECs were transfected with siRNAs targeting Notch4 (SiN4\#1 and 
SiN4\#2) or a non targeting scramble siRNA. Notch1, Notch2 and Notch4 mRNA steady states were analyzed by qRT-PCR 48 host-transfection. Results shown are means \pm SEM from 3 independent experiments and are express as a percentage of control expression (medium).

Figure 5.

\section{TNF-mediated Notch regulation and EC apoptosis}

(A) A representative Western blot analysis showing caspase-3 and caspase-7 cleavage in ECs silenced for Notch4 or overexpressing Notch2NICD. Immunoblotting was performed using specific anti-cleaved or total form of caspases antibodies. Blots were reprobed with anti-GAPDH antibodies (B, C, D, E) Caspase-3 activity in EC transduced with AdN2ICD or AdGFP and/or transfected with either non targeting (scramble) or Notch4 siRNAs. Caspase3-like activity was visualized in individual, live ECs by time lapse fluorescence videomicroscopy. Cultures were incubated with cell-permeable PhiPhiLux $-G_{2} D_{2}$ substrate at $37^{\circ} \mathrm{C}, 5 \% \quad \mathrm{CO}_{2}$. The quenched fluorescence PhiPhiLuxG2D2 substrate is cleaved intracellularly by caspase-3-like proteases, greatly enhancing red fluorescence. Non apoptotic ECs expressing Notch2NICD-GFP or GPF alone appeared in green while apoptotic ECs are round red fluorescent cells. ECs were examined under $a \times 20$ objective and the total number of apoptotic cells determined by counting. (B, C,D) Results are expressed as the percentage of caspase-3 positive EC $\left({ }^{*} p<0.05\right)$. (E) Representative pictures of fields analyzed.

\section{Figure 6.}

TNFa-dependent Notch regulation upon inflammation in vivo. Rats $(n=3)$ were treated intravenously with rat TNF $\alpha(10 \mu \mathrm{g} / \mathrm{kg})$ for $0,1,4$ or $6 \mathrm{~h}$. Lungs, heart and kidneys were collected and frozen for mRNA and protein analysis. Real-time quantitative PCR was used for mRNA analysis. Results shown are the mean \pm SEM of three independent experiments and are expressed as relative expression, calculated according to the $2^{-\Delta \Lambda \mathrm{Ct}}$ method, after 
normalization with $\beta$-actin levels ( ${ }^{*} p<0.05$ versus control). (A) Basal levels of Notch2 and Notch4 transcripts in heart, kidney and lung from untreated rats; ${ }^{*} \mathrm{p}<0.05$ versus transcript level in heart. (B) Time-course analysis of transcript levels in lung in response to TNFa ( ${ }^{*} \mathrm{p}<0.05$ versus untreated rats). (C, D) Western blotting for Notch2, Notch4, cleaved (Asp175) and total caspase-3, cleaved (Asp198) and total caspase-7 and tubulin in lung in response to TNFa (4h). A representative experiment out of 3 independent experiments is shown. 


\section{References}

1. Artavanis-Tsakonas $\mathrm{S}$, Rand $\mathrm{MD}$ and Lake RJ, Notch signaling: cell fate control and signal integration in development. Science 284(5415): 770-6, 1999.

2. Iso $\mathrm{T}$, Hamamori $\mathrm{Y}$ and Kedes $\mathrm{L}$, Notch signaling in vascular development. Arterioscler Thromb Vasc Biol 23(4): 543-53, 2003.

3. Radtke F and Raj K, The role of Notch in tumorigenesis: oncogene or tumour suppressor? Nat Rev Cancer 3(10): 756-67, 2003.

4. Maillard I, Adler SH and Pear WS, Notch and the immune system. Immunity 19(6): 781-91, 2003.

5. Limbourg FP, Takeshita K, Radtke F, Bronson RT, Chin MT and Liao JK, Essential role of endothelial Notch1 in angiogenesis. Circulation 111(14): 1826-32, 2005.

6. Pober JS, Endothelial activation: intracellular signaling pathways. Arthritis Res 4 Suppl 3: S109-16, 2002.

7. Mantovani A, Bussolino F and Introna M, Cytokine regulation of endothelial cell function: from molecular level to the bedside. Immunol Today 18(5): 231-40, 1997.

8. Pober JS, Immunobiology of human vascular endothelium. Immunol Res 19(2-3): 225-32, 1999.

9. Pober JS and Cotran RS, The role of endothelial cells in inflammation. Transplantation 50: 537-44, 1990.

10. Briscoe $\mathrm{DM}$, Alexander $\mathrm{SI}$ and Lichtman $\mathrm{AH}$, Interactions between $\mathrm{T}$ lymphocytes and endothelial cells in allograft rejection. Curr Opin Immunol 10(5): 525-31, 1998.

11. Leong $K G$ and Karsan $A$, Recent insights into the role of Notch signaling in tumorigenesis. Blood 107(6): 2223-33, 2006.

12. Noseda M, McLean G, Niessen K, Chang L, Pollet I, Montpetit R, Shahidi R, Dorovini-Zis K, Li L, Beckstead B, Durand RE, Hoodless PA and Karsan A, Notch activation results in phenotypic and functional changes consistent with endothelial-to-mesenchymal transformation. Circ Res 94(7): 910-7, 2004.

13. Williams CK, Li JL, Murga M, Harris AL and Tosato G, Up-regulation of the Notch ligand Deltalike 4 inhibits VEGF-induced endothelial cell function. Blood 107(3): 931-9, 2006.

14. MacKenzie F, Duriez $P$, Wong F, Noseda M and Karsan A, Notch4 Inhibits Endothelial Apoptosis via RBP-J\{kappa\}-dependent and -independent Pathways. J Biol Chem 279(12): 11657-11663, 2004.

15. Ridgway J, Zhang G, Wu Y, Stawicki S, Liang WC, Chanthery Y, Kowalski J, Watts RJ, Callahan C, Kasman I, Singh M, Chien M, Tan C, Hongo JA, de Sauvage F, Plowman G and Yan M, Inhibition of DIl4 signalling inhibits tumour growth by deregulating angiogenesis. Nature 444(7122): 1083-7, 2006.

16. Noseda M, Chang L, McLean G, Grim JE, Clurman BE, Smith LL and Karsan A, Notch activation induces endothelial cell cycle arrest and participates in contact inhibition: role of p21Cip1 repression. Mol Cell Biol 24(20): 8813-22, 2004. 
17. Boulday G, Coupel S, Coulon F, Soulillou JP and Charreau B, Antigraft antibody-mediated expression of metalloproteinases on endothelial cells. Differential expression of TIMP-1 and ADAM-10 depends on antibody specificity and isotype. Circ Res 88(4): 430-7, 2001.

18. Boulday G, Coulon F, Fraser CC, Soulillou JP and Charreau B, Transcriptional up-regulation of the signaling regulatory protein LNK in activated endothelial cells. Transplantation 74(9): 13524, 2002.

19. Coupel S, Leboeuf F, Boulday G, Soulillou JP and Charreau B, RhoA activation mediates phosphatidylinositol 3-kinase-dependent proliferation of human vascular endothelial cells: an alloimmune mechanism of chronic allograft nephropathy. J Am Soc Nephrol 15(9): 2429-39, 2004.

20. Fitau J, Boulday G, Coulon F, Quillard T and Charreau B, The adaptor molecule Lnk negatively regulates tumor necrosis factor-alpha-dependent VCAM-1 expression in endothelial cells through inhibition of the ERK1 and -2 pathways. J Biol Chem 281(29): 20148-59, 2006.

21. Six E, Ndiaye D, Laabi $Y$, Brou C, Gupta-Rossi N, Israel A and Logeat F, The Notch ligand Delta1 is sequentially cleaved by an ADAM protease and gamma-secretase. Proc Natl Acad Sci U S A 100(13): 7638-43, 2003.

22. Quillard T, Coupel S, Coulon F, Fitau J, Chatelais M, Cuturi MC, Chiffoleau E and Charreau B, Impaired Notch4 activity elicits endothelial cell activation and apoptosis: implication for transplant arteriosclerosis. Arterioscler Thromb Vasc Biol 28(12): 2258-65, 2008.

23. Quillard T, Devalliere J, Chatelais M, Coulon F, Seveno C, Romagnoli M, Barille Nion S and Charreau B, Notch2 signaling sensitizes endothelial cells to apoptosis by negatively regulating the key protective molecule survivin. PLoS One 4(12): e8244, 2009.

24. Livak KJ and Schmittgen TD, Analysis of relative gene expression data using real-time quantitative PCR and the 2(-Delta Delta C(T)) Method. Methods 25(4): 402-8, 2001.

25. Iso $T$, Kedes $L$ and Hamamori $Y$, HES and HERP families: multiple effectors of the Notch signaling pathway. J Cell Physiol 194(3): 237-55, 2003.

26. Madge LA and Pober JS, TNF signaling in vascular endothelial cells. Exp Mol Pathol 70(3): 317-25, 2001.

27. Aguilera C, Hoya-Arias R, Haegeman G, Espinosa L and Bigas A, Recruitment of IkappaBalpha to the hes 1 promoter is associated with transcriptional repression. Proceedings of the National Academy of Sciences of the United States of America 101(47): 16537-42, 2004.

28. Liu ZJ, Shirakawa T, Li Y, Soma A, Oka M, Dotto GP, Fairman RM, Velazquez OC and Herlyn $M$, Regulation of Notch1 and DIl4 by vascular endothelial growth factor in arterial endothelial cells: implications for modulating arteriogenesis and angiogenesis. Mol Cell Biol 23(1): 14-25, 2003.

29. Matsumoto T, Turesson I, Book M, Gerwins P and Claesson-Welsh L, p38 MAP kinase negatively regulates endothelial cell survival, proliferation, and differentiation in FGF-2stimulated angiogenesis. The Journal of cell biology 156(1): 149-60, 2002. 
30. Hiratochi M, Nagase H, Kuramochi $\mathrm{Y}$, Koh CS, Ohkawara $\mathrm{T}$ and Nakayama K, The Delta intracellular domain mediates TGF-beta/Activin signaling through binding to Smads and has an important bi-directional function in the Notch-Delta signaling pathway. Nucleic acids research 35(3): 912-22, 2007.

31. Monsalve E, Perez MA, Rubio A, Ruiz-Hidalgo MJ, Baladron V, Garcia-Ramirez JJ, Gomez JC, Laborda $J$ and Diaz-Guerra MJ, Notch-1 up-regulation and signaling following macrophage activation modulates gene expression patterns known to affect antigenpresenting capacity and cytotoxic activity. J Immunol 176(9): 5362-73, 2006.

32. Krebs LT, Xue Y, Norton CR, Shutter JR, Maguire M, Sundberg JP, Gallahan D, Closson V, Kitajewski J, Callahan R, Smith GH, Stark KL and Gridley T, Notch signaling is essential for vascular morphogenesis in mice. Genes Dev 14(11): 1343-52, 2000.

33. Henderson AM, Wang SJ, Taylor AC, Aitkenhead M and Hughes CC, The basic helix-loophelix transcription factor HESR1 regulates endothelial cell tube formation. J Biol Chem 276(9): 6169-76, 2001.

34. Liu ZJ, Xiao M, Balint K, Soma A, Pinnix CC, Capobianco AJ, Velazquez OC and Herlyn M, Inhibition of endothelial cell proliferation by Notch1 signaling is mediated by repressing MAPK and PI3K/Akt pathways and requires MAML1. Faseb J 20(7): 1009-11, 2006.

35. Chi JT, Chang HY, Haraldsen G, Jahnsen FL, Troyanskaya OG, Chang DS, Wang Z, Rockson SG, van de Rijn M, Botstein D and Brown PO, Endothelial cell diversity revealed by global expression profiling. Proc Natl Acad Sci U S A 100(19): 10623-8, 2003.

36. Espinosa L, Ingles-Esteve J, Robert-Moreno A and Bigas A, IkappaBalpha and p65 regulate the cytoplasmic shuttling of nuclear corepressors: cross-talk between Notch and NFkappaB pathways. Mol Biol Cell 14(2): 491-502, 2003.

37. Sweeney C, Morrow D, Birney YA, Coyle S, Hennessy C, Scheller A, Cummins PM, Walls D, Redmond EM and Cahill PA, Notch 1 and 3 receptor signaling modulates vascular smooth muscle cell growth, apoptosis, and migration via a CBF-1/RBP-Jk dependent pathway. Faseb J 18(12): 1421-3, 2004.

38. Ohishi K, Varnum-Finney B, Flowers D, Anasetti C, Myerson D and Bernstein ID, Monocytes express high amounts of Notch and undergo cytokine specific apoptosis following interaction with the Notch ligand, Delta-1. Blood 95(9): 2847-54, 2000.

39. Saito T, Chiba S, Ichikawa M, Kunisato A, Asai T, Shimizu K, Yamaguchi T, Yamamoto G, Seo S, Kumano K, Nakagami-Yamaguchi E, Hamada Y, Aizawa $S$ and Hirai H, Notch2 is preferentially expressed in mature $B$ cells and indispensable for marginal zone $B$ lineage development. Immunity 18(5): 675-85, 2003.

40. Witt CM, Hurez V, Swindle CS, Hamada Y and Klug CA, Activated Notch2 potentiates CD8 lineage maturation and promotes the selective development of B1 B cells. Mol Cell Biol 23(23): 8637-50, 2003.

41. Al-Lamki RS, Wang J, Vandenabeele P, Bradley JA, Thiru S, Luo D, Min W, Pober JS and Bradley JR, TNFR1- and TNFR2-mediated signaling pathways in human kidney are cell typespecific and differentially contribute to renal injury. Faseb J 19(12): 1637-45, 2005. 
Table 1.

Oligonucleotide primer pairs and PCR conditions for semi-quantitative analysis

\begin{tabular}{|c|c|c|c|}
\hline Target & $\begin{array}{c}\text { Forward } \\
\text { (Sequence 5'-3') }\end{array}$ & $\begin{array}{c}\text { Reverse } \\
\text { (Sequence 5'-3') }\end{array}$ & $\begin{array}{l}\text { Number of } \\
\text { PCR cycles }\end{array}$ \\
\hline Notch 2 & GCAGGAGGTGGATGTGTTAG & CCAGGATCAGGGGTGTAGAG & 21 \\
\hline Notch 4 & TGTTTGATGGCTACGACTGT & TCCTTACCCAGAGTCCTACC & 27 \\
\hline hes 1 & AGAGGCGGCTAAGGTGTTTG & GAGAGGTGGGTTGGGGAGTT & 25 \\
\hline hes 2 & TCATCCTGCCGCTGCTGGG & TACCCTGGAGCTGCTGAAG & 30 \\
\hline hes 3 & TCСTCСTCCCCGAAAGTCTC & CACGACCAGAACGGACGACT & 35 \\
\hline hes 4 & СТCAGCTCAАAАСССТСАТС & GCGGTACTTGCCCAGAACGG & 20 \\
\hline hes 5 & TGGGGTTGTTCTGTGTTTGC & CAC & 35 \\
\hline hes 6 & CCCTGAGGCTGAACTGAGTC & СТАССССАССАСАТСТGАAС & 30 \\
\hline hes 7 & TAGGGGTGGGGTAGAGACTC & AGACAGAAGGGAAGGGAAAG & 35 \\
\hline hey 1 & CAGGCAACAGGGGGTAAAGG & GTGGAGCGGATGATGGTGGT & 27 \\
\hline hey 2 & GTCGCCTCTCCACAACTTCA & CTGGACGTGGCTGATACTGA & 27 \\
\hline hey 3 & TGGGACAGGATTCTTTGATG & GGTAAGCAGGAGAGGAGACA & 35 \\
\hline VCAM-1 & AATGTTGCCCCCAGAGATAC & TCTCCTGTCCTCGCTTTTTTT & 27 \\
\hline$\beta$-actin & TCTGGCACCACACCTTCTAC & CAGCTTCTCCTTAATGTCAC & 18 \\
\hline
\end{tabular}


Figure 1

HAEC

A

\begin{tabular}{llll}
\multicolumn{4}{c}{ TNFa (h) } \\
\hline 0 & 6 & $12 \quad 24$
\end{tabular}

Notch 2

Notch 4

ß-actin
HUVEC

B

\begin{tabular}{llll}
\multicolumn{4}{c}{ TNF $\alpha(\mathrm{h})$} \\
\hline $\begin{array}{llll}0 & 6 & 12 & 24\end{array}$
\end{tabular}

Notch 2

Notch 4

ß-actin
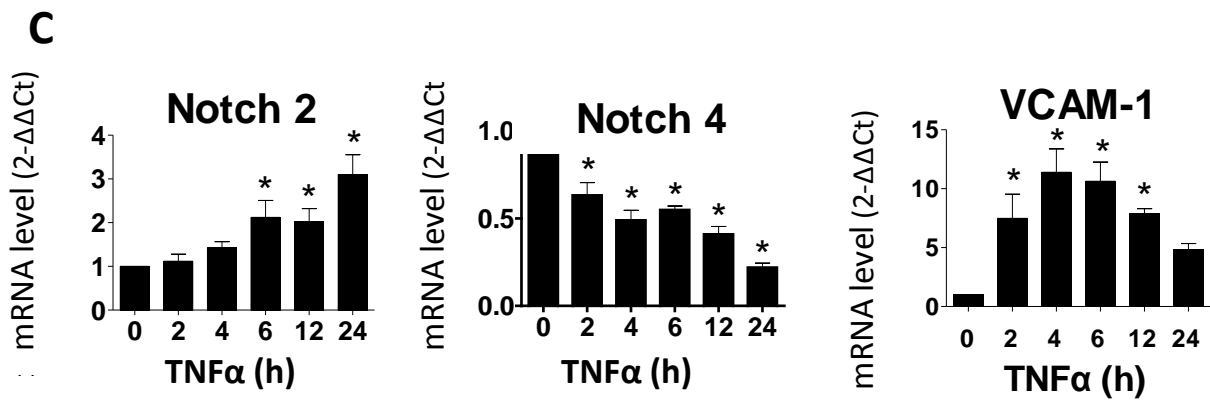

D

$$
\begin{array}{llllll}
\multicolumn{6}{c}{\mathrm{TNFa}(\mathrm{h})} \\
\hline 0 & 2 & 4 & 6 & 12 & 24
\end{array}
$$

Notch 2

\section{$\begin{array}{lllllll}0 & 2 & 4 & 6 & 12 & 24\end{array}$}

Notch 4

$110 \mathrm{kDa}$

Tubulin

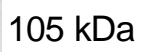

$50 \mathrm{kDa}$

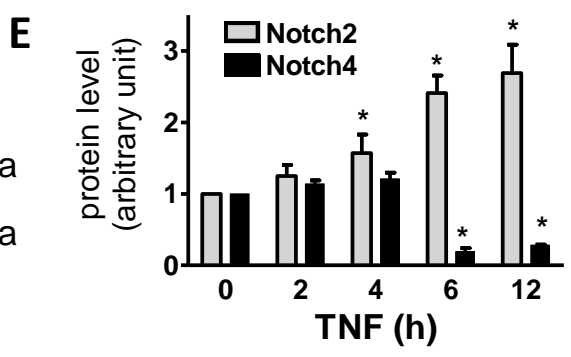


Figure 2
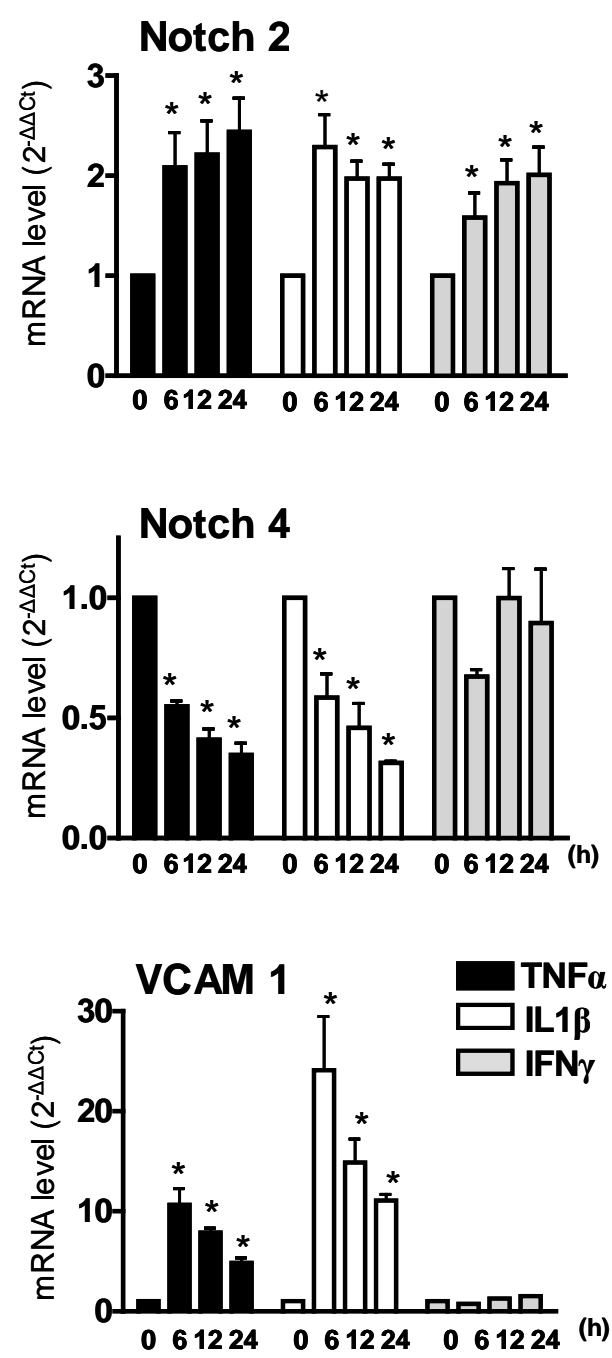


\section{Figure 3}
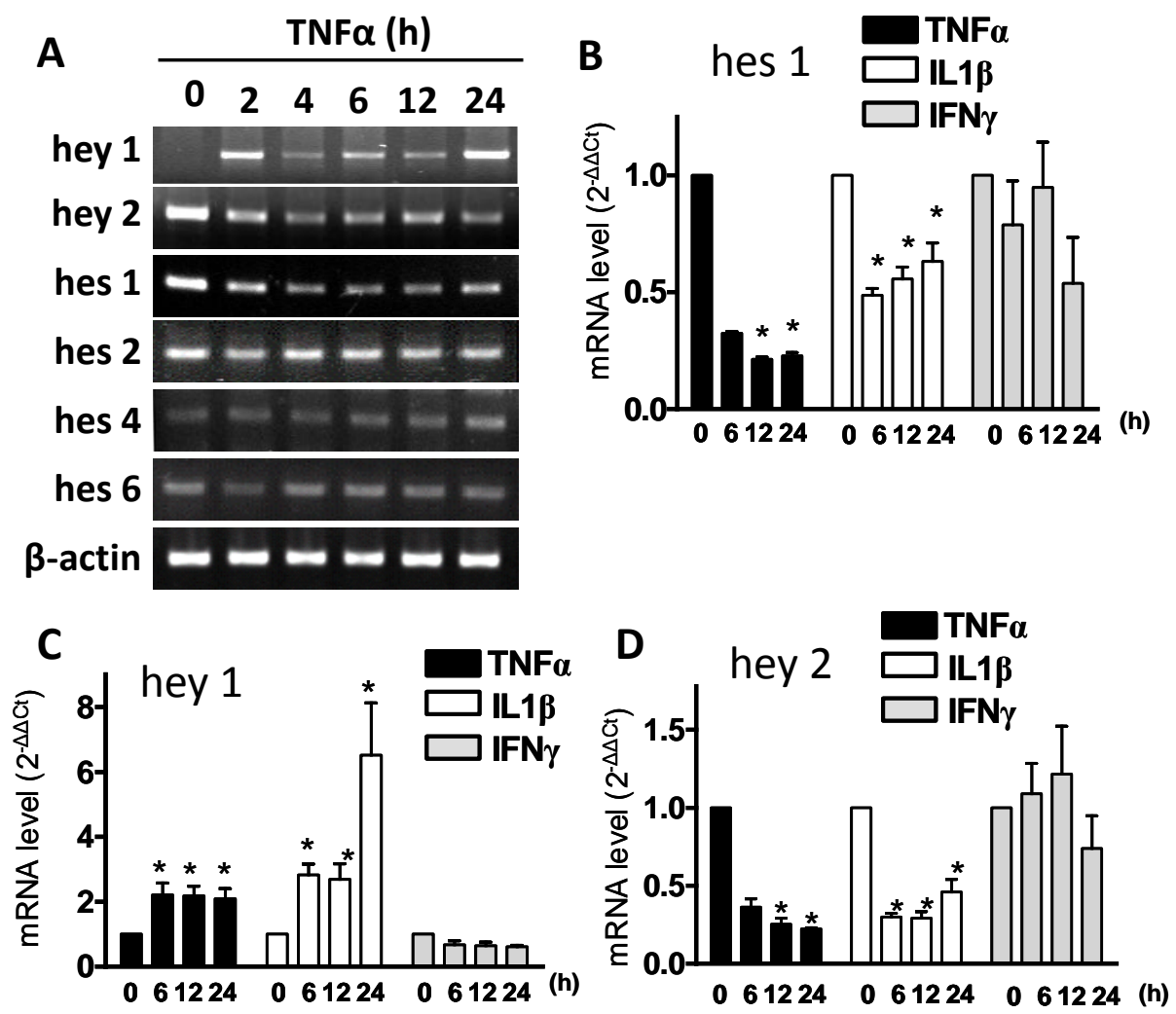
Figure 4

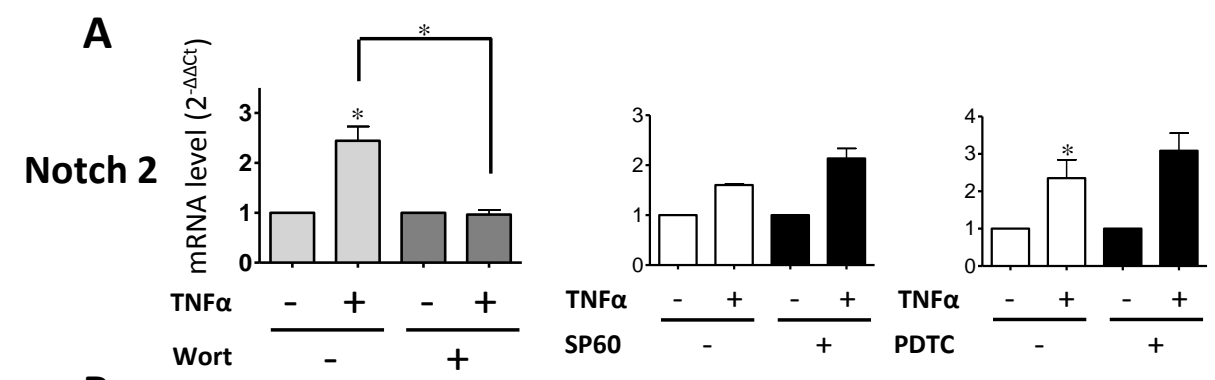

B

hey1
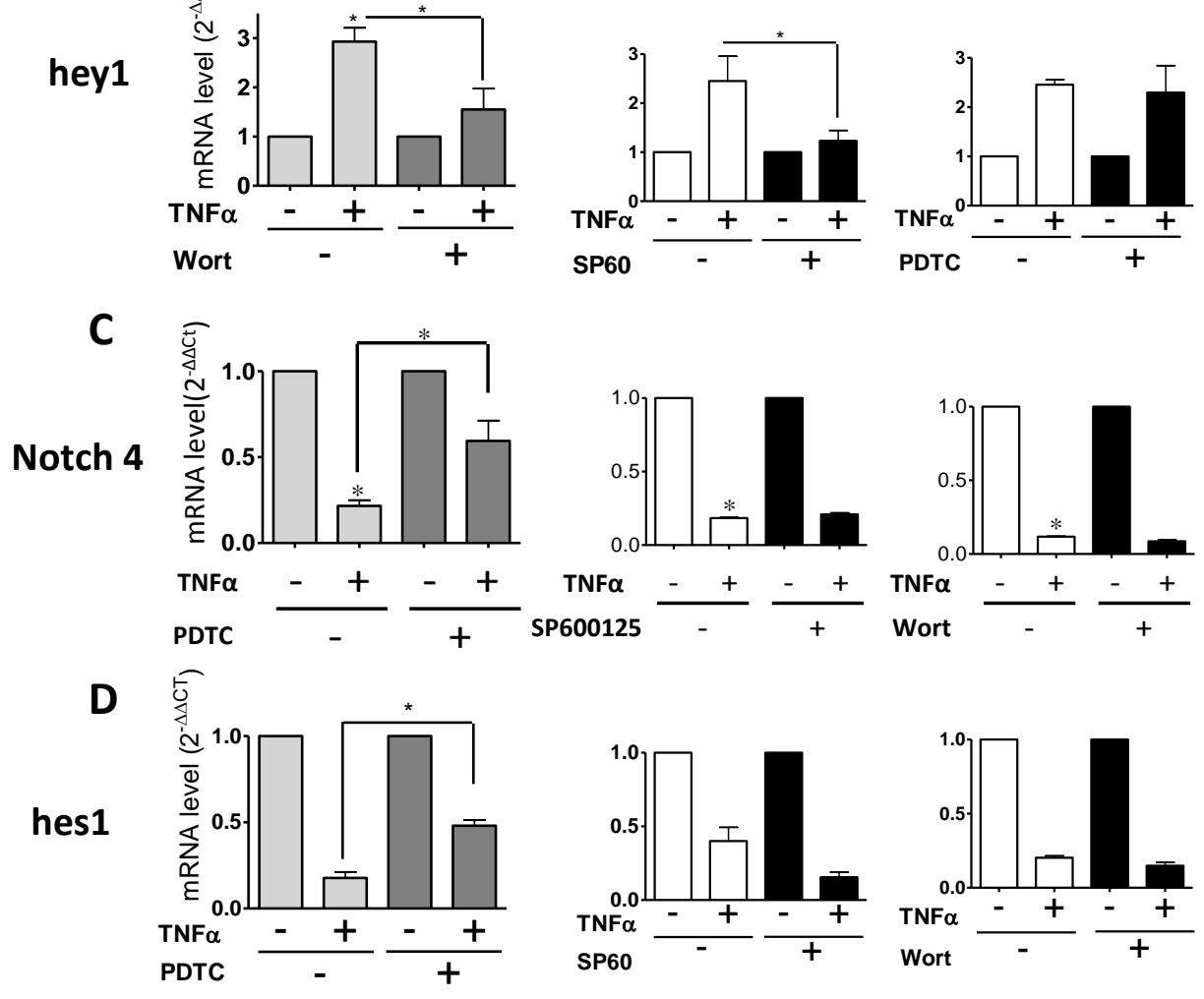

E

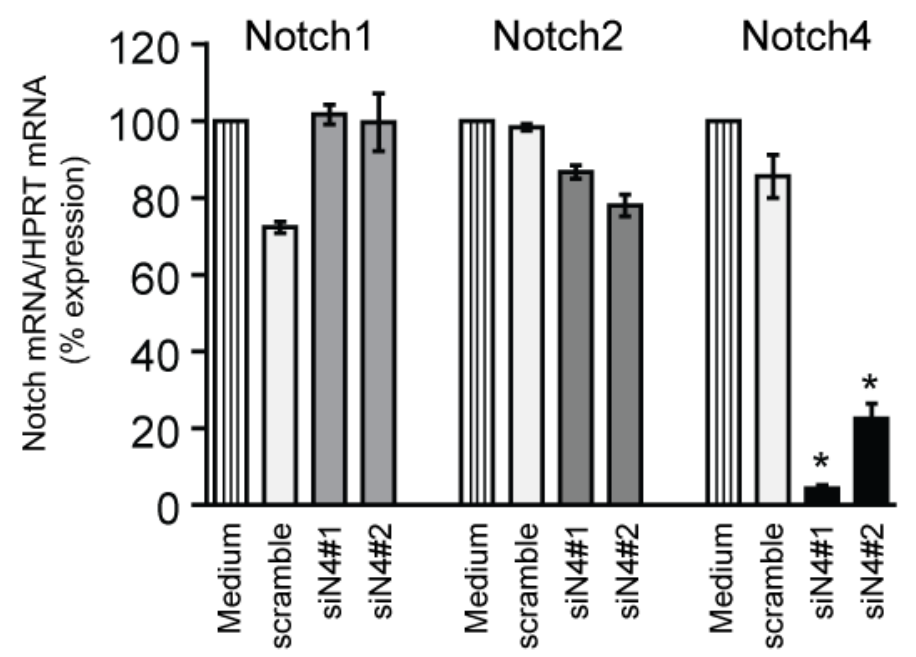


Figure 5
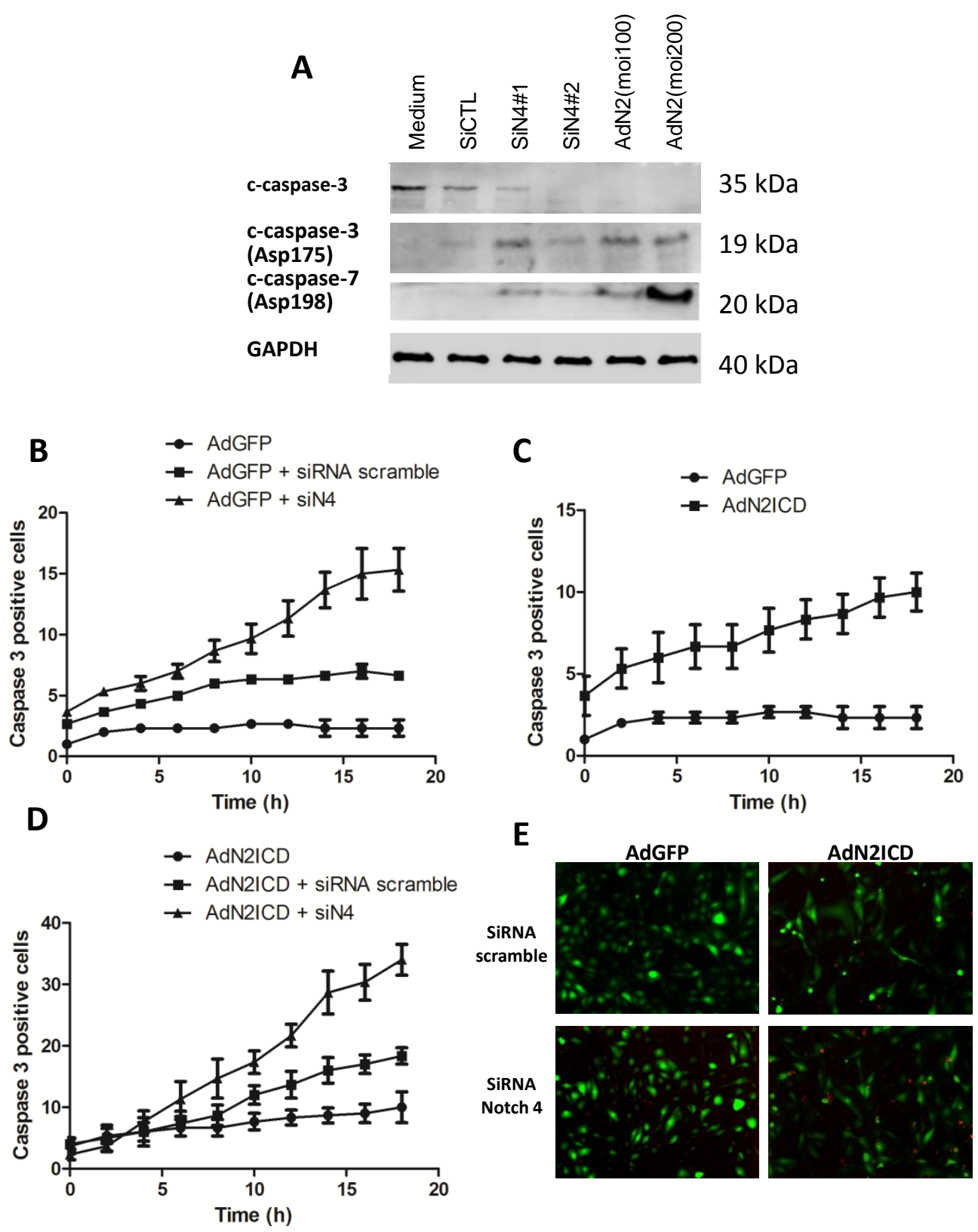
Figure 6

A
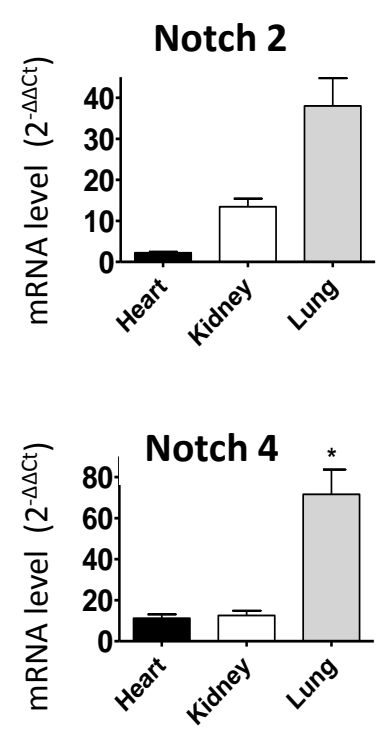

B

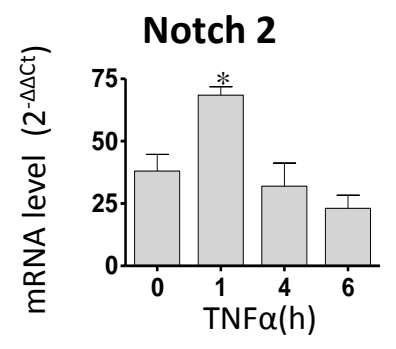

Notch 4
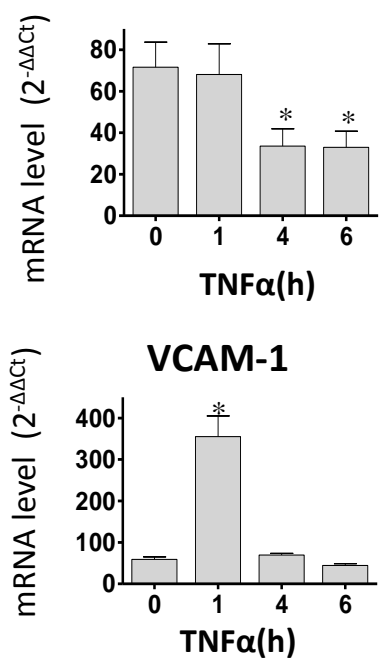

C
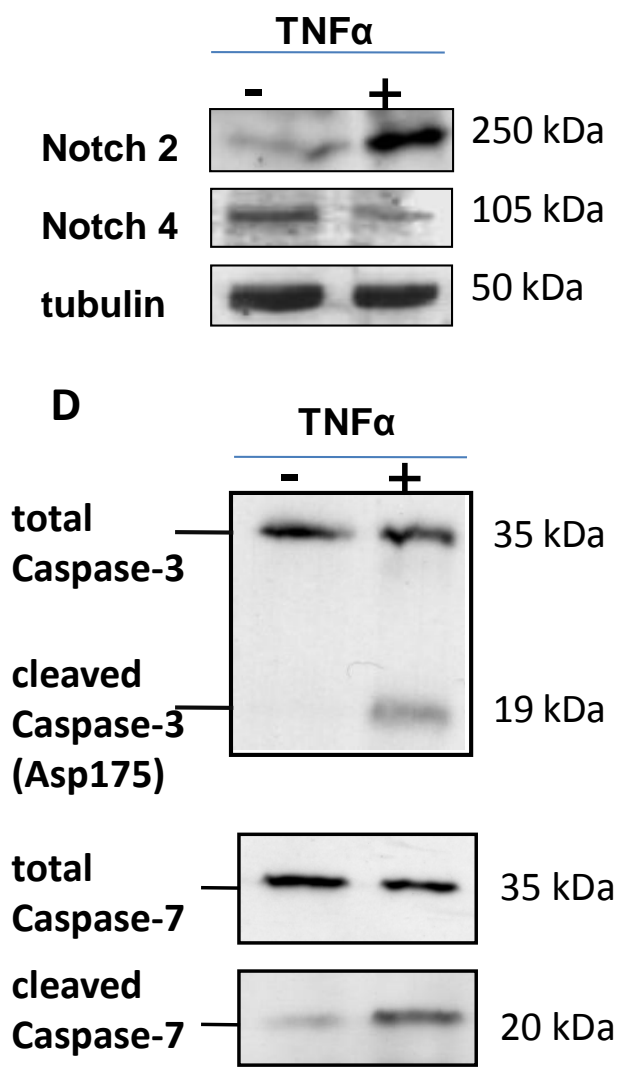

(Asp198) 


\section{Graphical Abstract}

TNF promotes apoptosis in endothelial cells through a downregulation of Notch activity and a phenotypic switch where Notch4 is replaced by Notch2

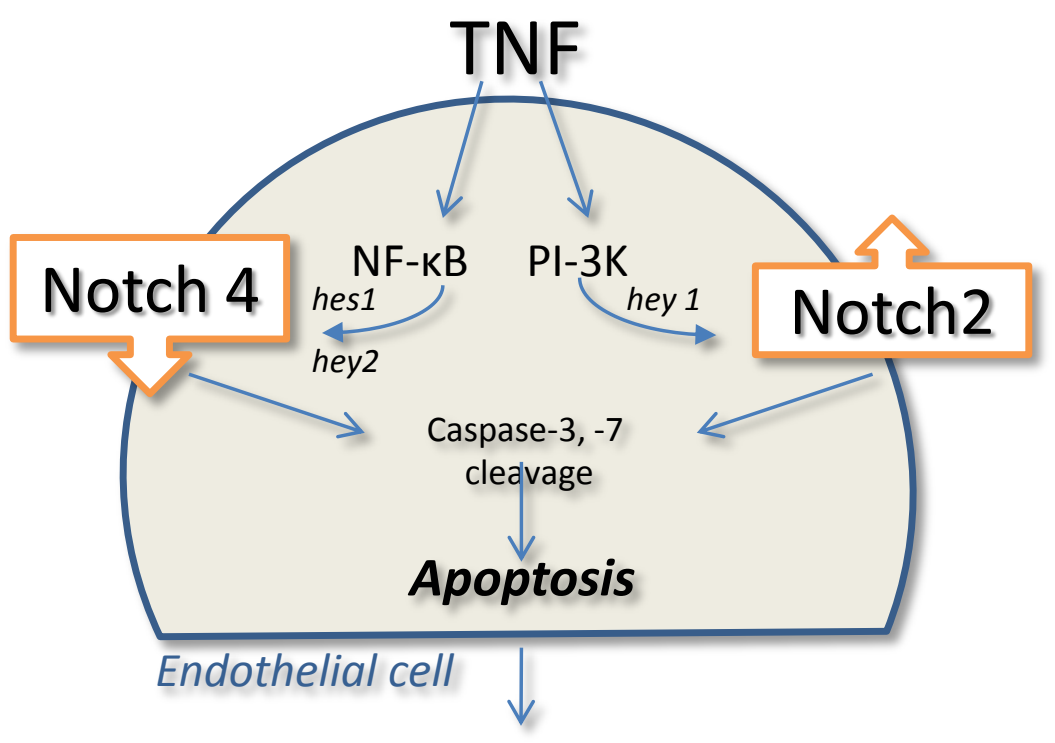

Vascular injury 